\title{
PERBEDAAN KEMAMPUAN PEMECAHAN MASALAH MATEMATIS DAN SIKAP SISWA YANG DIBERI PEMBELAJARAN KOOPERATIF TIPE THINK PAIR SHARE DENGAN TIPE THINK PAIR SQUARE PADA SMP NEGERI PEMATANGSIANTAR
}

\author{
Theresia Monika Siahaan \\ Prodi Pendidikan Matematika FKIP UHN Pematangsiantar \\ theresia_monika86@yahoo.com
}

\begin{abstract}
The aims of this research is (1) to know there is the diffrentiation of students' mathematical problem solving who teach between Kooperatif Think Pair Share and Think Pair Square, (2) to know there is the diffrentation of student's attitude Kooperatif Think Pair Share and Think Pair Square, and (3) describe the process problem solving between cooperatif Think Pair Share and Think Pair Square. The research is kuasi eksperiment. The population of this research are all of students in SMP N Pematangsiantar, and the sample chosen is random, SMP Negeri 9 and SMP Negeri 3 Pematangsiantar with VII4 and VII-5 as the eksperiment class 1 and VII-5 and VII-7 as eksperimen class 2 with 68 students every class eksperiment. This research uses two ways ANACOVA test. The results of this research shown that: (1) there is diffrentation in mathematical problemsolving from students who teach between Kooperatif Think Pair Share and Think Pair Square, (2) the atttitude of students who teach with kooperatif Think Pair Share better than the students who teach with Think Pair Square, and (3) the process of students answers who are taught with the Think Pair Share better than Think Pair Square.
\end{abstract}

Keywords: Think Pair Share, Think Pair Square, Problem Solving Mathematical Ability, and Student's Attitude

\begin{abstract}
Abstrak. Tujuan penelitian ini adalah (1) untuk mengetahui apakah terdapat perbedaan kemampuan pemecahan masalah antara siswa yang menggunakan model pembelajaran kooperatif tipe think pair share dengan think pair square pada materi persamaan dan pertidaksamaan linear satu variabel, (2) untuk mengetahui apakah terdapat perbedaan sikap siswa antara siswa yang diberi pembelajaran kooperatif tipe think pair share dengan think pair square, dan (3) untuk mengetahui proses penyelesaian masalah yang dibuat oleh siswa terhadap tes kemampuan pemecahan masalah matematis antara pembelajaran kooperatif tipe think pair share dengan kooperatif tipe think pair square. Jenis penelitian ini adalah kuasi eksperimen. Populasi dalam penelitian ini adalah seluruh siswa SMP Negeri Pematangsiantar, dan sampelnya dipilih secara acak yaitu SMP Negeri 9 dan SMP Negeri 3 Pematangsiantar dengan VII-4 dan VII-5 sebagai kelas eksperimen 1 dan VII-5 dan VII-7 sebagai kelas eksperimen 2 yang masing-masing berjumlah 68 orang. Penelitian ini menggunakan uji Anakova. Hasil penelitian menunjukkan bahwa: (1) terdapat perbedaan kemampuan pemecahan masalah matematis antara siswa yang diberi model pembelajaran think pair share dengan siswa yang diberi model pembelajaran think pair square, (2) Sikap siswa terhadap matematika yang memperoleh pembelajaran kooperatif tipe Think Pair Share lebih baik secara signifikan dari siswa yang memperoleh pembelajaran kooperatif tipe Think Pair Square, dan (3) Proses penyelesaian jawaban siswa dengan mengunakan model pembelajaran Think Pair Share lebih baik dibandingkan dengan model pembelajaran Think Pair Square.
\end{abstract}

Kata Kunci: Think Pair Share, Think Pair Square, Kemampuan Pemecahan Masalah Matematik, dan Sikap Siswa

\section{PENDAHULUAN}

Pendidikan merupakan usaha sadar agar manusia dapat mengembangkan potensi dirinya melalui proses pembelajaran. Pendidikan mempunyai pengaruh besar terhadap 
peningkatan mutu pendidikan yang merupakan salah satu titik berat pembangunan di bidang pendidikan untuk menghadapi tantangan sesuai dengan tuntutan perubahan lokal, nasional, dan global. Di dalam Undang-undang nomor 20 tahun 2003 tentang sistem pendidikan Nasional Bab II pasal 3 dikemukakan, "Pendidikan nasional berfungsi mengembangkan kemampuan dan membentuk watak serta peradaban bangsa yang bermartabat dalam rangka mencerdaskan kehidupan bangsa, bertujuan untuk berkembangnya potensi peserta didik agar menjadi manusia yang beriman dan bertaqwa kepada Tuhan Yang Maha Esa, berakhlak mulia, sehat, berilmu, cakap, kreatif, mandiri, dan menjadi Warga Negara yang demokratis serta bertanggung jawab." (UU Sisdiknas, 2003).

Pendidikan yang dimaksudkan disini adalah proses yang berhubungan berhubungan dengan mata pelajaran. Tujuan mata pelajaran pada intinya adalah setelah belajar siswa dapat berkembang sikap, pengetahuan dan keterampilannya yang sesuai dengan karakteristik matematika. Dalam hal berkembangnya (tumbuhnya) sikap, siswa diharapkan dapat berpikir kritis, logis, analitik dan kreatif, menghargai kegunaan matematika dalam kehidupan yang ditunjukkan dengan tumbuhnya rasa ingin tahu, perhatian, dan minat dalam mempelajari matematika, ulet dan percaya diri dalam memecahkan masalah kehidupannya sehari-hari. Dalam hal berkembangnya pengetahuan, siswa diharapkan agar dapat memahami konsep matematika, menjelaskan keterkaitan antar konsep dan mengaplikasikannya dalam kegiatan pemecahan masalah. Dalam hal berkembangnya keterampilan, siswa diharapkan dapat memecahkan masalah, dan mengkomunikasikan gagasan serta budaya bermatematika, menggunakan penalaran pada pola dan sifat, melakukan manipulasi matematika dalam membuat generalisasi, menyusun bukti, atau menjelaskan gagasan dan pernyataan matematika.

Sejalan dengan itu pemerintah juga terus berupaya mengembangkan sistem pembelajaran matematika disekolah supaya menjadi lebih baik. Salah satu kebijakan yang diambil oleh pemerintah adalah dengan dikeluarkannya Permendiknas tentang tujuan mata pelajaran matematika. Menurut Peraturan Menteri Pendidikan Nasional (Permendiknas) No. 23 tahun 2006 Tentang Standar. Beberapa uraian di atas secara eksplisit jelas menunjukkan pentingnya mempelajari matematika dalam menata kemampuan berpikir para siswa, bernalar, memecahkan masalah, berkomunikasi, mengaitkan materi matematika dengan keadaan sesungguhnya, serta mampu menggunakan dan memanfaatkannya. Kemampuan-kemampuan itu disebut daya matematik (mathematical power) atau keterampilan matematika (doing math).

Salah satu doing math yang erat kaitannya dengan karakteristik matematika adalah kemampuan pemecahan masalah. Aqib (2013:112) menyatakan Pemecahan masalah merupakan suatu cara yang merangsang berpikir dan menggunakan wawasan tanpa melihat kualitas pendapat yang disampaikan oleh siswa. Gagne (dalam Yamin, 2012: 81) mengatakan pemecahan masalah adalah tipe belajar yang tingkahnya paling tinggi dan kompleks dibandingkan dengan tipe belajar lainnya. Walaupun kemampuan pemecahan masalah merupakan kemampuan yang tidak mudah dicapai, akan tetapi karena kepentingan dan kegunaannya maka kemampuan pemecahan masalah ini hendaknya diajarkan kepada siswa pada semua tingkatan. Berkaitan dengan hal ini, Ruseffendi (1991:341) mengemukakan beberapa alasan soal-soal tipe pemecahan masalah diberikan kepada siswa: (1) dapat menimbulkan keingintahuan dan adanya motivasi, menumbuhkan sifat kreatif; (2) di samping memiliki pengetahuan dan keterampilan (berhitung dan lain-lain), disyaratkan adanya kemampuan untuk terampil 
membaca dan membuat pernyataan yang benar; (3) dapat menimbulkan jawaban yang asli, baru, khas, dan beraneka ragam, dan dapat menambah pengetahuan baru; (4) dapat meningkatkan aplikasi dari ilmu pengetahuan yang sudah diperolehnya; (5) Mengajak siswa memiliki prosedur pemecahan masalah, mampu membuat analisis dan sintesis, dan dituntut untuk membuat evaluasi tehadap hasil pemecahannya; dan (6) Merupakan kegiatan yang penting bagi siswa yang melibatkan bukan saja satu bidang studi tetapi (bila diperlukan) banyak bidang studi, malahan dapat melibatkan pelajaran lain diluar pelajaran sekolah, merangsang siswa untuk menggunakan segala kemampuannya. Ini penting bagi siswa untuk menghadapi kehidupannya kini dan dikemudian hari.

Hudoyo (1988:175) mengemukakan pandangannya tentang langkah pemecahan masalah yaitu: (1) mengerti/memahami masalah, misalkan merumuskan dan menjawab pertanyaan apa yang ditanyakan atau dibuktikan, (2) merencanakan penyelesaian termasuk mengumpulkan informasi yang berkaitan dengan persyaratan yang telah ditentukan, menganalisis informasi dengan menggunakan analogi masalah (3) melaksanakan penyelesaian dengan pengecekan kembali setiap langkah yang dilalui, (4) melihat kembali untuk mengetahui kecocokan hasil apakah ada hasil lain /atau cara lain penyelesaian yang berbeda hasilnya juga sama.

Rendahnya kemampuan pemecahan masalah matematik siswa, sebagaimana terlihat dari hasil tes PISA (Programme for International StudAent ssesment) yang diselenggarakan pada tahun 2009 bertujuan untuk mengukur tingkat kemampuan pemecahan masalah dan penalaran matematika siswa. Dari 65 negara yang ikut serta Indonesia berada pada peringkat 61, sedangkan Thailand (50), Australia (15), Kazastan (53), Jepang (9), Singapura (2) dan Shanghai-Cina (1). Data ini menunjukkan bahwa Negara kita, peringkat Indonesia baru bisa menduduki 10 besar terbawah dari 65 negara. Dengan capaian tersebut, menunjukkan rata-rata kemampuan siswa relatif lebih baik dalam menyelesaikan soal-soal tentang fakta dan prosedur, akan tetapi sangat lemah dalam menyelesaikan soal-soal tidak rutin yang berkaitan dengan pembuktian, pemecahan masalah yang memerlukan penalaran matematika, menemukan generalisasi atau konjektur, dan menemukan hubungan antara data-data atau fakta yang diberikan.

Pembelajaran yang memfasilitasi peserta didik agar memiliki kompetensi (sikap, pengetahuan dan keterampilan) yang memadai untuk eksis pada abad 21 tersebut bercirikan sebagai berikut: 1) Pembelajaran diarahkan untuk mendorong siswa mencari tahu dari berbagai sumber belajar, dengan melakukan observasi, bukan diberi tahu, 2) Pembelajaran diarahkan untuk mampu merumuskan masalah (menanya), bukan hanya menyelesaikan masalah (menjawab), 3) Pembelajaran diarahkan untuk melatih berfikir analitis (pengambilan keputusan) bukan berfikir mekanistis (rutin), dan 4) Pembelajaran menekankan pentingnya kerjasama dan kolaborasi dalam menyelesaikan masalah

Pembelajaran dengan ciri-ciri tersebut adalah pembelajaran yang tidak cukup hanya mengakomodasi proses eksplorasi, elaborasi, dan konfirmasi, namun juga mengakomodasi proses mengamati, menanya, menalar, dan mencoba. Pembelajaran dengan ciri-ciri tersebut, tidak lain adalah pembelajaran yang menerapkan metode ilmiah. Pendekatan pembelajaran yang menerapkan tahapan metode ilmiah dinyatakan sebagai pendekatan saintifik atau pendekatan saintifik (scientific approach). Selanjutnya scientific approach dalam tulisan ini diterjemahkan sebagai pendekatan ilmiah. Pendekatan ilmiah merupakan suatu cara atau mekanisme pembelajaran untuk 
memfasilitasi siswa agar mendapatkan pengetahuan atau keterampilan dengan prosedur yang didasarkan pada suatu metode ilmiah. Pendekatan saintifik atau pendekatan ilmiah ini memerlukan langkah-langkah pokok sebagai berikut (permendikbud nomor 81A, 2013), yaitu: mengamati, menanya, mengumpulkan informasi, mengasosiasikan/ mengolah informasi, dan mengkomunikasikan.

Rusefendi mengatakan bahwa, "Minat dengan prestasi belajar itu berkorelasi positif tetapi rendah. Walaupun korelasinya rendah, bila kita belajar sesuatu... sebaiknya kita berminat mengerjakannya." Padahal kenyataan dilapangan tidaklah sesuai dengan yang diharapkan. Hasil angket minat siswa terhadap pelajaran yang disenanginya di salah satu SMP di kota Pematangsiantar, dari 32 siswa diperoleh data sebagai berikut : 14 siswa (56\%) menyenangi pelajaran olahraga, 6 siswa (24\%) menyenangi seni lukis, 3 siswa (12\%) menyenangi Teknologi Informasi (TIK), 2 siswa (8\%) menyenangi pelajaran matematika, dan sisanya pelajaran yang lain. Dari hasil angket di atas terlihat bahwa sedikitnya siswa yang menyenangi pelajaran matematika dibandingkan terhadap mata pelajaran yang lain. Hal ini menunjukkan adanya sikap negatif siswa (tidak menyenangi/ menyukai) terhadap pelajaran matematika dibandingkan dengan mata pelajaran lainnya.

Sikap siswa terhadap matematika sangat erat kaitannya dengan minat siswa terhadap matematika, bahkan sebagian dari sikap merupakan akibat dari minat, misalnya siswa yang berminat terhadap matematika maka ia akan suka mengerjakan tugas matematika, ini pertanda bahwa siswa tersebut bersikap positif terhadap matematika. Hal senada diungkapkan Ruseffendi (1991:134) bahwa, "Sikap seseorang terhadap sesuatu itu erat sekali kaitannya dengan minat; sebagian bisa tumpang tindih, sebagian dari sikap itu merupakan akibat dari minat." Misalnya, karena siswa berminat terhadap matematika ia suka mengerjakan Pekerjaan Rumah (PR). Itu suatu pertanda bahwa siswa itu bersikap positif terhadap matematika". Dari ungkapan di atas disimpulkan bahwa tanpa adanya minat, siswa akan sulit untuk menumbuhkan keinginan dan kesenangan dalam belajar matematika apalagi matematika tidak mudah untuk dipelajari. Sehingga hampir semua siswa dari setiap jenjang pendidikan kurang berminat dalam belajar matematika.

Sikap siswa terhadap matematika merupakan salah satu komponen dari aspek afektif, yang merupakan kecenderungan seseorang untuk merespon secara positif (suka) atau negatif (tidak suka) terhadap suatu objek atau konsep matematika. Menurut Sarwono (2010:201) sikap mengandung tiga komponen yaitu: (1) Komponen Kognitif, berupa keyakinan, ide atau konsep tentang suatu objek. Komponen ini memberikan respon terhadap pertanyaan atau pernyataan tentang apa yang dipikirkan atau dipersepsikan tentang objek tersebut; (2) Komponen Afektif, berupa perasaan senang atau tidak senang terhadap suatu objek. Komponen ini memberikan respon terhadap apa yang dirasakan perihal objek tersebut; (3) Komponen Behaviour, berupa perilaku yang mengikuti perasan mendekat atau menghindar. Saat proses pembelajaran matematika dengan pendekatan konvensional berlangsung terjadi perbedaan sikap yang mencolok antara siswa berkemampuan tinggi dengan siswa berkemampuan rendah yaitu sikap siswa berkemampuan tinggi lebih baik daripada sikap siswa berkemampuan rendah. Ini ditandai dengan timbulnya sikap negatif dari siswa berkemampuan rendah terhadap matematika seperti : tidak mengerjakan tugas, mengggangu teman yang lagi belajar dan bolos (tidak berada di kelas) saat pelajaran matematika sedang berlangsung. 
Sikap seseorang terhadap sesuatu itu erat sekali kaitannya dengan minat; sebagian bisa tumpang tindih, sebagian dari sikap itu merupakan akibat dari minat (dalam Ruseffendi, 1991:234). Sikap siswa terhadap matematika merupakan salah satu komponen aspek afektif, yang merupakan kecenderungan siswa untuk merespon secara positif (suka) atau negatif (tidak suka) terhadap suatu objek atau konsep matematika. Adakalanya ditemukan siswa yang sangat aktif (hyperkinetic) dan ada pula siswa yang pendiam, tidak sedikit juga ditemukan siswa yang mempunyai motivasi belajar yang rendah. Sikap siswa merupakan faktor yang sangat menentukan dalam interaksi pembelajaran. Untuk mengetahui bagaimana sikap siswa terhadap matematika, Ruseffendi (1991:235) mengemukakan bahwa komponen-komponen sikap yang perlu diukur adalah: Kepercayaan Diri dalam Belajar Matematika, Kecemasan dalam Belajar Matematika, Kegunaan Matematika, Matematika sebagai Bidangnya Pria, Sikap terhadap Keberhasilan, Dorongan untuk Berhasil dalam Matematika, dan Kesan Siswa Mengenai Sikap Orang Lain (Guru, Ayah, dan Ibu) terhadap Diri Siswa.

Untuk menyiasati permasalahan tersebut, perlu adanya perbaikan dan penyempurnaan ke arah sistem pendidikan ataupun dalam hal yang langsung berkaitan dengan praktek pembelajaran. Misalkan dalam menggunakan model pembelajaran. Dari beberapa model pembelajaran kooperatif ada dua pembelajaran kooperatif yang menarik dan dapat membantu siswa meningkatkan kemampuan pemecahan masalah matematis dan sikap siswa. Model pembelajaran tersebut adalah pembelajaran kooperatif tipe Think Pair Share (TPS) dan Think Pair Square (TPSq). Pembelajaran kooperatif tipe TPS pertama kali dikembangkan oleh Frank Lyman dan koleganya di Universitas Maryland. Think Pair Share (TPS) merupakan jenis pembelajaran kooperatif yang dirancang untuk mengatasi pola interaksi siswa. Think Pair Share (TPS) merupakan perpaduan antara sikap siswa dan belajar secara kelompok. Model pembelajaran kooperatif tipe Think Pair Share (TPS) membantu siswa menginterpretasikan ide mereka bersama dan memperbaiki pemahaman. Model pembelajaran kooperatif tipe Think Pair Share (TPS) cocok digunakan di SMP karena kondisi siswa SMP yang masih dalam masa remaja membuat mereka menyukai hal baru dan lebih terbuka dengan teman sebaya dalam memecahkan permasalahan yang mereka hadapi. Arends menyatakan think pair share merupakan suatu cara yang efektif untuk membuat variasi suasana pola diskusi kelas ( dalam Trianto, 2010: 132).

Menurut Istarani (2012:67) prosedurnya adalah sebagai berikut: 1) Guru menyampaikan inti materi dan kompetensi yang ingin dicapai, 2) Peserta didik diminta untuk berfikir tentang materi/ permasalahan yang disampaikan guru, 3) Peserta didik diminta berpasangan dengan teman sebelahnya (kelompok 2 orang) dan mengutarakan hasil pemikiran masing-masing, 4) Guru memimpin hasil pleno kecil, tiap kelompok mengemukakan hasil diskusinya, 5) Berawal dari kegiatan tersebut, guru mengarahkan pembicaraan pada pokok permasalahan dan menambah materi yang belum diungkapkan para peserta didik, 6) Guru memberi kesimpulan, 7) Penutup.

Sebagai langkah awal adalah think yaitu berpikir, setiap siswa diberi kesempatan untuk membaca, memahami dan memikirkan kemungkinan jawaban dan membuat catatan tentang hal-hal yang tidak dipahaminya. Kemudian pair (berpasangan) dimana pada tahap ini siswa mendiskusikan hasil pemikiran sendiri dengan pasangan kelompoknya yang sudah ditentukan. Dalam tahap ini siswa harus bisa menentukan metode penyelesaian yang lebih tepat dari banyaknya argumen yang ada dalam menyelesaikan masalah. Pada langkah akhir adalah pasangan akan share (berbagi) 
yaitu guru meminta pasangan-pasangan untuk berbagi dengan keseluruhan kelas yang telah mereka bicarakan. Pada tahap ini setiap pasangan yang ada harus dapat menyatukan semua informasi yang diperolehnya dari pasangan lain untuk mendapatkan ide yang tepat dalam menyelesaikan masalah.

Pembelajaran tipe think pair share tidak jauh berbeda dengan pembelajaran tipe think pair square. Perbedaan yang ada hanya terletak pada tahap square (berempat), dimana keberhasilan kelompok merupakan tanggung jawab dari setiap siswa. Pada tahap ini juga siswa di tuntut menemukan solusi yang tepat tipe dari uraian yang telah dikemukakan di atas dari setiap ide yang diberikan oleh anggota kelompoknya. Dimana setiap ide yang ada dalam kelompok harus bisa dijelaskan siswa agar kelompok lebih mudah dalam memahami masalah yang ada.

Menurut Anita Lie (2010:58) terdapat empat tahap dalam teknik think pair square yaitu: 1) Guru membagi siswa dalam kelompok berempat dan memberikan tugas kepada semua kelompok; 2) Setiap siswa memikirkan dan mengerjakan tugas tersebut sendiri; 3 ) iswa berpasangan dengan salah satu rekan dalam kelompok dan berdiskusi dengan pasangannya; 4) Kedua pasangan bertemu kembali dalam kelompok berempat, siswa memiliki kesempatan untuk membagikan hasil kerja kepada kelompok berempat.

Penelitian yang dilakukan oleh Hernawati (2007) mengenai penerapan pembelajaran cooperative learning tipe Think Pair Share (TPS) untuk meningkatkan hasil belajar siswa kelas VIII SMPN 14 Tegal dalam pokok bahasan sistem persamaan linear dua variabel. Hasil penelitiannya adalah penerapan model pembelajaran cooperative learning tipe Think Pair Share (TPS) dapat meningkatkan hasil belajar siswa kelas VIII SMPN 14 Tegal dalam pokok bahasan sistem persamaan linear dua variabel.

Masih tentang model pembelajaran kooperatif tipe Think Pair Share (TPS), penelitian yang dilakukan Muzayyanah (2009) tentang model pembelajaran kooperatif tipe TPS untuk meningkatkan pemecahan masalah matematika siswa SMA Negeri 1 Godean, diperoleh kesimpulan bahwa pembelajaran matematika dengan menggunakan model pembelajaran kooperatif tipe TPS mampu meningkatkan kemampuan pemecahan masalah matematika siswa kelas XI IPA 2 SMA Negeri 1 Godean. Setelah dilaksanakan pembelajaran matematika dengan menggunakan model kooperatif tipe TPS di kelas XI IPA 2 SMA Negeri 1 Godean terjadi peningkatan kemampuan pemecahan masalah matematika siswa.

\section{METODE}

Penelitian ini merupakan penelitian eksperimen semu (quasi eksperimen) yang membandingkan dua modelpembelajaran yaitu model pembelajaran kooperatif tipe think pair share dan model pembelajaran kooperatif tipe think pair square. Untuk menentukan Perbedaan kemampuan pemecahan masalah matematis dan sikap siswa yang diberi pembelajaran kooperatif tipe think pair share dengan tipe think pair square pada smp negeri pematang siantar. Penelitian ini dilaksanakan di SMP Negeri 3 Pematangsiantar dan SMPNegeri 9 Pematangsiantar kelas VII di Kota Pematangsiantar. Populasi dalam penelitian ini adalah seluruh siswa kelas VII SMP Negeri di Kota Pematangsiantar yang terakreditasi. Pemilihan siswa SMP kelas VII sebagai objek penelitian didasarkan pada pertimbangan tingkat kognitif siswa. Dari sekolah tersebut kemudian dipilih dua kelas yaitu kelas VII-4 dan VII-5 sebagai kelas eksperimen 1 dan kelas VII-5 dan VII- 7 sebagai kelas eksperimen 2. 
Penelitian memiliki beberapa variable yaitu variabel bebas dalam penelitian ini adalah model pembelajaran kooperatif tipe think pair sharedan model pembelajaran kooperatif tipe think pair square, variabel perlakuan adalah model pembelajaran kooperatif tipe think pair share untuk kelompok eksperimen 1 dan model pembelajaran kooperatif tipe think pair square untuk kelompok eksperimen 2 dan variabel kontrolnya adalah:

a) Guru yang mengajar kelompok pembelajaran kooperatif tipe think pair share dan kelompok pembelajaran kooperatif tipe think pair square adalah sama atau setara yaitu guru bidang studi matematika dengan Ijazah Sarjana (S1) Pendidikan Matematika.

b) Materi pelajaran yang diajarkan di kelompok pembelajaran kooperatif tipe think pair share dan kelompok pembelajaran kooperatif tipe think pair squareadalah sama, yaitu persamaan dan pertidaksamaan linear satu variabel yang termuat dalam kurikulum 2013 untuk SMP.

Waktu, jumlah waktu yang digunakan dalam proses pembelajaran kooperatif tipe think pair share dan kelompok pembelajaran kooperatif. Pada desain ini kelas eksperimen 1 diberi perlakuan pembelajaran kooperatif tipe think pair share dan kelas eksperimen 2 diberi perlakuan pembelajaran kooperatif tipe think pair squareyang diberi pretes dan postes. Adapun tujuan diberikan pretes untuk melihat kesetaraan antara subjek penelitian. Sedangkan postes untuk melihat perbedaan kemampuan pemecahan masalah dan sikap siswa.

\section{HASIL DAN PEMBAHASAN \\ Hasil}

Analisis inferensial tes hasil kemampuan pemecahan masalah matematis siswa ditunjukkan untuk menguji hipotesis yaitu: (1) kemampuan pemecahan masalah matematika antara siswa yang diberi model pembelajaran think pair share dengan siswa yang diberi model pembelajaran think pair square. Kemampuan pemecahan masalah rata-rata proporsi skor pretes dan postespada kelas model pembelajaran think pair share adalah 18,61 dan 80,84. Bila diperhatikan rata-rata proporsi skor postes terjadi peningkatan rata-rata proporsi skor sebesar 62,23. Sedangkan kelompok model pembelajaran think pair square yaitu 26,59 dan 70,38 terjadi peningkatan rata-rata proporsi skor sebesar 43,79. Selisih proporsi pretes dan postesuntuk kelompok model pembelajaran think pair share lebih besar dari selisih proporsi skor pretes dan postes untuk kelas model pembelajaran think pair square. Hal ini memberi petunjuk bahwa model pembelajaran think pair share dapat meningkatkan pencapaian kemampuan pemecahan masalah matematis siswa daripada model pembelajaran think pair square.

Berdasarkan kriteria ketuntasan belajar untuk kemampuan pemecahan masalah bahwa banyaknya siswa kelas model pembelajaran think pair share yang tuntas belajar hanya 62 orang dari 68 siswa atau 91,18\% dari jumlah siswa. Banyaknya siswa yang tuntas untuk kelas model pembelajaran think pair square adalah 48 orang dari 68 siswa atau $70,59 \%$ dari jumlah siswa. Persentase ketuntasan siswa kelas model pembelajaran think pair share ini jauh lebih besar dari persentase ketuntasan siswa kelas model pembelajaran think pair square adalah sebesar $91,18 \%$.

Hasil tersebut menunjukkan bahwa model pembelajaran think pair shareyang didukung perangkat pembelajaran yang dikembangkan peneliti dapat meningkatkan jumlah siswa yang tuntas belajar untuk materi persamaan dan pertidaksamaan linear satu variabel. Sesuai dengan kriteria ketuntasan secara klasikal bahwa suatu 
pembelajaran dipandang telah tuntas jika terdapat $80 \%$ siswa yang telah memiliki nilai minimal $\geq 2,66$. Dengan demikian secara klasikal kelas model pembelajaran think pair share telah memenuhi kriteria ketuntasan belajar. Oleh karena ketuntasan hasil belajar dengan model pembelajaran think pair share lebih baik daripada ketuntasan hasil belajar model pembelajaran think pair square, hal tersebut mengindikasikan bahwa model pembelajaran think pair share baik diterapkan dalam pembelajaran matematika pada materipersamaan dan pertidaksamaan linear satu variabel.

Untuk melihat langkah penyelesaian siswa maka hasilnya dilihat pada uraian berikut: bahwa proses jawaban siswa pada aspek memahami masalah yang berada pada interval $15<\mathrm{x} \leq 25$ untuk kategori baik, pada model pembelajaran think pair share dan model pembelajaran think pair square.Jumlah siswa yang menjawab soal dengan langkah penyelesaian yang lengkap dan benar terdapat 4 orang siswa $(5,88 \%)$ dan 0 orang siswa $(0 \%)$. Pada kategori cukup yang berada pada interval $10<\mathrm{x} \leq 15$ yang menjawab soal dengan langkah tidak lengkap dan jawaban benar terdapat 60 $(88,23 \%)$ orang siswa dan $45(66,17 \%)$ orang siswa. Sedangkan Pada kategori kurang baik yang berada pada interval $0<\mathrm{x} \leq 10$ yang menjawab soal dengan langkah tidak lengkap dan jawaban benar terdapat $4(5,88 \%)$ orang siswa dan $23(33,82 \%)$ orang siswa. Dengan rata-rata skor jawaban siswa di kelas model pembelajaran think pair share dan model pembelajaran think pair square pada aspek memahami masalah 12,87 dan 11 .

Proses jawaban siswa pada aspek merencanakan penyelesaian di kelas model pembelajaran think pair sharedan kelas model pembelajaran think pair squareuntuk kategori baik yang berada pada interval $10<\mathrm{x} \leq 16$ jumlah siswa yang menjawab soal dengan langkah penyelesaian yang lengkap dan benar terdapat $50(73,53 \%)$ orang siswa dan $60(88,24 \%)$ orang siswa. Pada kategori cukup yang berada pada interval $5<$ $\mathrm{x} \leq 10$ yang menjawab soal dengan langkah tidak lengkap dan jawaban benar terdapat $18(26,47 \%)$ orang siswa dan $8(11,76 \%)$ orang siswa. Sedangkan Pada kategori kurang baik yang berada pada interval $0<\mathrm{x} \leq 5$ yang menjawab soal dengan langkah tidak lengkap dan jawaban benar terdapat $0(0 \%)$ orang siswa dan $0(0 \%)$ orang siswa. Dengan rata-rata skor jawaban siswa di kelas model pembelajaran think pair share dan model pembelajaran think pair square pada aspek merencanakan penyelesaian 11,94 dan 12,5 .

Pada aspek menyelesaikan masalah di kelas model pembelajaran think pair share dan model pembelajaran think pair square untuk kategori baik yang berada pada interval $15<\mathrm{x} \leq 20$ jumlah siswa yang menjawab soal dengan langkah penyelesaian yang lengkap dan benar terdapat $23(33,82 \%)$ orang siswa dan $2(2,94 \%)$ orang siswa. Pada kategori cukup yang berada pada interval $10<\mathrm{x} \leq 15$ yang menjawab soal dengan langkah tidak lengkap dan jawaban benar terdapat $37(54,41 \%)$ orang siswa dan 38 $(55,88 \%)$ orang siswa. Sedangkan Pada kategori kurang baik yang berada pada interval $0<\mathrm{x} \leq 10$ yang menjawab soal dengan langkah tidak lengkap dan jawaban benar terdapat $8(11,76 \%)$ orang siswa dan $28(41,18 \%)$ orang siswa. Dengan rata-rata skor jawaban siswa di kelas model pembelajaran think pair sharedan model pembelajaran think pair square pada aspek menyelesaikan masalah adalah 13,85 dan 11 .

Sedangkan pada aspek melakukan pengecekan di kelas model pembelajaran think pair share dan model pembelajaran think pair square untuk kategori baik yang berada pada interval $10<\mathrm{x} \leq 16$ jumlah siswa yang menjawab soal dengan langkah penyelesaian yang lengkap dan benar terdapat $56(82,35 \%)$ orang siswa dan 36 
$(52,94 \%)$ orang siswa. Pada kategori cukup yang berada pada interval $5<\mathrm{x} \leq 10$ yang menjawab soal dengan langkah tidak lengkap dan jawaban benar terdapat $12(17,65 \%)$ orang siswa dan $32(47,05 \%)$ orang siswa. Sedangkan Pada kategori kurang baik yang berada pada interval $0<\mathrm{x} \leq 5$ yang menjawab soal dengan langkah tidak lengkap dan jawaban benar terdapat $0(0 \%)$ orang siswa dan $0(0 \%)$ orang siswa. Dengan rata-rata skor jawaban siswa di kelas model pembelajaran think pair share dan model pembelajaran think pair square pada aspek melakukan pengecekan 13,07 dan 11.

Analisis hasil sikap siswa terhadap matematika diuraikan sebagai berikut: diketahui bahwa nilai t hitung $=4,53$. Sedangkan nilai $\mathrm{t}$ tabel $=1,97$ dengan $\mathrm{db}=\mathrm{n}_{1}+$ $\mathrm{n}_{2}-2=134$ pada taraf signifikansi 5\% (uji pihak kanan) dapat dilihat di tabel t. Karena nilai t hitung lebih besar dari t tabel dapat disimpulkan bahwa hipotesis nol ditolak dengan kata lain mengatakan bahwa sikap siswa terhadap matematika yang mengikuti pembelajaran dengan strategi Think Pair Share lebih baik dibandingkan dengan sikap siswa yang mengikuti pembelajaran Think Pair Square.

\section{Pembahasan}

Berdasarkan hasil penelitian yang telah dilakukan, kemampuan pemecahan Pembahasan hasil penelitian berikut ini adalah berdasarkan analisis data dan temuantemuan dilapangan. Selanjutnya untuk memberikan kontribusi ke arah perbaikan jika menerapkan model pembelajaran matematika di sekolah, perlu dikemukakan hal-hal yang positif untuk menunjang keberhasilan dan mengatasi hambatan-hambatan yang ditemukan pada eksperimen tentang pembelajaran kooperatif tipe Think Pair Share, kemampuan pemecahan masalah matematis siswa, sikap siswa.

\section{Kemampuan Pemecahan Masalah}

Kemampuan Pemecahan masalah adalah kemampuan siswa dalam menyelesaikan masalah matematika dengan memperhatikan proses menemukan jawaban berdasarkan langkah-langkah pemecahan masalah (memahami masalah; merencanakan pemecahan masalah; menyelesaikan masalah; dan melakukan pengecekan kembali) yang dikemukakan polya. Berdasarkan hasil analisis data kemampuan pemecahan masalah matematis diperoleh data bahwa kelas yang menggunakan model pembelajaran TPS lebih baik daripada yang menggunakan pembelajaran TPSq.

Berdasarkan rata-rata proporsi skor pretes dan postes pada kelas model pembelajaran think pair share adalah 18,61 dan 80,84 . Bila diperhatikan rata-rata proporsi skor postes terjadi peningkatan rata-rata proporsi skor sebesar 62,23. Sedangkan kelompok model pembelajaran think pair square yaitu 26,59 dan 70,38 terjadi peningkatan rata-rata proporsi skor sebesar 43,79. Selisih proporsi pretes dan postesuntuk kelompok model pembelajaran think pair share lebih besar dari selisih proporsi skor pretes dan postes untuk kelas model pembelajaran think pair square. Hal ini memberi petunjuk bahwa model pembelajaran think pair share dapat meningkatkan pencapaian kemampuan pemecahan masalah matematis siswa daripada model pembelajaran think pair square.

Hal ini sejalan dengan penelitian Rahmi (2012) bahwa terjadi peningkatan kemampuan pemecahan masalah matematis siswa yang menggunakan model pembelajaran TPS daripada yang memperoleh pembelajaran biasa. 


\section{Sikap Siswa terhadap Matematika}

Seperti telah dikemukakan sebelumnya, bahwa Sikap terhadap matematika adalah suatu kecenderungan seseorang dalam merespon pembelajaran matematika yang disampaikan guru baik secara positif (menyukai atau menyenangi pembelajaran matematika) atau secara negatif (tidak menyukai atau tidak menyenangi pembelajaran matematika). Sarwono (2010:205) menyebutkan sikap dapat diukur dengan indikatorindikator: a) Sikap terhadap mata pelajaran, b) Sikap terhadap guru mata pelajaran, c) Sikap terhadap proses pembelajaran.

\section{KESIMPULAN}

Berdasarkan hasil pembahasan disimpulkan hal-hal berikut: 1) Terdapat perbedaan kemampuan pemecahan masalah matematika antara siswa yang diberi model pembelajaran think pair share dengan siswa yang diberi model pembelajaran think pair square. Hal ini terlihat dari hasil analisis kovarians (ANAKOVA) untuk $\mathrm{F}_{\text {hitung }}$ adalah 16,187 lebih besar dari $\mathrm{F}_{\text {tabel }}$ adalah 3,91 dan konstanta regresi untuk model pembelajaran think pair share adalah 48,30 lebih besar dari model pembelajaran think pair square yaitu 42,67. Rata-rata postes kemampuan pemecahan masalah matematis siswa yang memperoleh model pembelajaran think pair shareadalah 80,84 dan rata-rata kemampuan pemecahan masalah matematis siswa yang memperoleh model pembelajaran think pair square adalah 70,38; 2) Terdapat perbedaan sikap siswa terhadap matematika yang memperoleh pembelajaran kooperatif tipe Think Pair Share dari siswa yang memperoleh pembelajaran kooperatif tipe Think Pair Square; dan 3) Proses penyelesaian jawaban siswa dengan mengunakan model pembelajaran Think Pair Share lebih baik dibandingkan dengan model pembelajaran Think Pair Square. Hal ini ditunjukkan dengan jawaban siswa dalam menyelesaikan tes kemampuan pemecahan masalah matematis lebih baik pada kelas model pembelajaran think pair sharedibandingkan dengan model pembelajaran think pair square.

\section{DAFTAR PUSTAKA}

Aqib, Z. 2013. Model-model, Media, dan Strategi Pembelajaran Kontekstual (Inovatif). Bandung: CV Yrama Widya.

Depdiknas. 2013. Kurikulum 2013 Standar Isi Mata Pelajaran Matematika. Jakarta: Departemen Pendidikan Nasional.

Hudojo, H. 1988. Mengajar Belajar Matematika. Jakarta: Departemen Pendidikan dan Kebudayaan Direktorat Jendral Pendidikan Tinggi Proyek Pengembangan Lembaga Pendidikan dan Tenaga Kependidikan.

Istarani. 2012. 58 Model Pembelajaran Inovatif. Medan: Media Persada.

Lampiran Peraturan Menteri Pendidikan dan Kebudayaan No. 81A tahun 2013 mengenai Implementasi kurikulum.

Lampiran Peraturan Menteri No. 23 tahun 2006 mengenai Standar Isi.

Lie, A. 2010. Cooperative Learning. Mempraktekan Cooperative Learning RuangRuang Kelas. Jakarta: PT Gramedia.

Polya, G. 1945. How To Solve It. USA: Princeton University Press, Princeton, New Jersey.

Ruseffendi, E. T. 1991. Pengantar Kepada Membantu Guru Mengembangkan Kompetensinya dalam Pengajaran Matematika untuk Meningkatkan CBSA. Bandung: Tarsito. 
Sarwono, S. W. 2010. Pengantar Umum Psikologi. Jakarta: Bulan Bintang.

Trianto. 2010. Mendesain Model Pembelajaran Inovatif-Progresif. Jakarta: Prenada Media Group.

Undang-Undang Republik Indonesia Nomor 20 Tahun 2003. Tentang Sistem Pendidikan Nasional. Jakarta: Medya Duta.

Yamin, M. 2012. Taktik Mengembangkan Kemampuan Individual Siswa. Ciputat: Referensi (GP Press Group). 